\title{
Potentiated Opioid Analgesia in Norepinephrine Transporter Knock-Out Mice
}

\author{
Laura M. Bohn, Fei Xu, Raul R. Gainetdinov, and Marc G. Caron \\ Howard Hughes Medical Institute, Departments of Cell Biology and Medicine, Duke University Medical Center, Durham, \\ North Carolina 27710
}

\begin{abstract}
Several studies have shown that activation of $\alpha_{2}$-adrenergic receptors $\left(\alpha_{2}\right.$ ARs) leads to mild analgesic effects. Tricyclic antidepressants (TCAs), such as desipramine (DMI), which block norepinephrine transporters (NETs), also produce mild antinociception. The coadministration of either $\alpha_{2} \mathrm{AR}$ agonists or TCAs with opiates produces synergistically potentiated antinociception. It has been postulated that the analgesic effects of TCAs are determined by their ability to inhibit norepinephrine reuptake via interactions with the NET. To test this idea, we studied mice lacking a functional NET in spontaneous and morphine-induced antinociceptive paradigms. Morphine $(10 \mathrm{mg} / \mathrm{kg}$, s.c.) treatment produced greater analgesia, as assayed in the warm water tailflick assay, in NET-knock-out (-KO) mice than in wild-type (WT) mice. As anticipated, yohimbine, an inhibitor of $\alpha_{2} \mathrm{ARs}$, blocked this potentiation. Moreover, a warm water swim-stress paradigm, which is known to induce the release of endogenous opioids,
\end{abstract}

produced greater antinociception in NET-KO than in the WT mice. Naloxone, an inhibitor of opioid receptors, blocked the development of the swim-evoked analgesia in both WT and NET-KO mice, confirming the involvement of the endogenous opioid system. In the NET-KO mice, DMI did not further enhance analgesia but was still able to produce inhibitory effects on the locomotor activity of these mutants, suggesting that the effects of this TCA are not exclusively via interactions with the NET. In summary, these results demonstrate in a genetic model that both endogenous and exogenous opiate-mediated analgesia can be enhanced by elimination of the NET, indicating that the interaction of TCAs with NET mediates these effects.

Key words: adrenergic; monoamine transporters; opiates; opioid receptors; antinociception; tricyclic antidepressants; desipramine
In humans, as well as in mice, treatment with tricyclic antidepressants (TCAs) produces mild analgesia (Ward et al., 1979; Tura and Tura, 1990; Gray et al., 1999). TCAs that block norepinephrine transporters (NETs), such as desipramine (DMI), prevent the presynaptic reuptake of norepinephrine (NE) and lead to increased postsynaptic NE levels. The resulting increase of NE and the subsequent activation of $\alpha_{2}$-adrenergic receptors $\left(\alpha_{2} \mathrm{ARs}\right)$ in spinal cord neurons are thought to mediate TCA-induced antinociception (Howe and Yaksh, 1982; Howe et al., 1983; FleetwoodWalker et al., 1985; Yaksh, 1985; Solomon et al., 1989; Takano and Yaksh, 1992). This is consistent with the clinically proven efficacy of $\alpha_{2} \mathrm{AR}$ agonists in the treatment of pain associated with cancer in humans (Davis et al., 1991; Eisenach et al., 1995, 1996).

Direct activation of $\alpha_{2} \mathrm{ARs}$ has also been shown to potentiate morphine-induced spinal analgesia (Howe et al., 1983; Ossipov et al., 1990a,b; Roerig et al., 1992; Fairbanks and Wilcox, 1999). Interestingly, in addition to the mild analgesia reported after TCA treatment, a potentiation of opioid antinociception also occurs after coadministration of TCAs and morphine in both mice and humans (Kellstein et al., 1984, 1988; Hwang and Wilcox, 1987; Gray et al., 1998, 1999; Reimann et al., 1999). Although the limited availability of pharmacologically selective ligands has prevented delineation of the particular $\alpha_{2} \mathrm{AR}$ subtypes involved, many studies have implicated the $\alpha_{2 \mathrm{~A}} \mathrm{AR}$ as the target for adrenergic antinociception (Millan et al., 1994; Graham et al., 1997). In addition, studies using transgenic mice expressing a functionally compro-

Received Aug. 11, 2000; revised Sept. 27, 2000; accepted Oct. 2, 2000.

This work was supported in part by National Institutes of Health Grants NS-19576 and $\mathrm{MH}-40159$ and a neuroscience unrestricted award from Bristol Myers Squibb to M.G.C. M.G.C. is an Investigator of the Howard Hughes Medical Institute, L.M.B is supported by National Institutes of Health Grant DA-06023, and R.R.G. is a visiting researcher from the Institute of Pharmacology, Russian Academy of Medical Sciences (Baltiyskaya 8, 125315 Moscow, Russia). We thank J. Holt and S. Suter for excellent technical assistance.

Correspondence should be addressed to Dr. Marc G. Caron, Howard Hughes Medical Institute, Departments of Cell Biology and Medicine, Duke University Medical Center, Box 3287, Durham, NC 27710. E-mail: caron002@mc.duke.edu.

Copyright (C) 2000 Society for Neuroscience $0270-6474 / 00 / 209040-06 \$ 15.00 / 0$ mised $\alpha_{2 \mathrm{~A}} \mathrm{AR}$ support the idea that the $\alpha_{2 \mathrm{~A}} \mathrm{AR}$ is specifically involved in modulating spinal nociception (Lakhlani et al., 1997) and that this receptor is principally involved in the synergistic potentiation of morphine analgesia (Stone et al., 1998).

Recently, we generated by homologous recombination a knockout (KO) mouse lacking the NET (Xu et al., 2000). The NET-KO mice resemble mice treated with antidepressants in a number of tests classically used to assess the actions of antidepressants $(\mathrm{Xu}$ et al., 2000). In addition, $\mathrm{Xu}$ et al. (2000) showed that although brain tissue storage of $\mathrm{NE}$ is decreased, extracellular levels of $\mathrm{NE}$ are increased, indicating a potential for chronic activation of $\alpha_{2} \mathrm{ARs}$. These mice provide a genetic model in which we can assess the effect of the loss of NE reuptake on adrenergic-signaling systems without involving the administration of TCAs. Moreover, the contribution of TCAs, such as DMI, to behavioral parameters can be assessed in these mice that genetically lack the proposed target of such drugs.

\section{MATERIALS AND METHODS}

Animals. Mice were generated as described previously (Wang et al., 1999; $\mathrm{Xu}$ et al., 2000). Wild-type (WT) mice were littermates from the NET-KO heterozygous cross and were used as controls in these assays. Both males and females were tested in each assay. Initially, the results from males and females were analyzed separately, but results were ultimately combined because no significant differences were found between the genders. All experiments were conducted in accordance with the National Institutes of Health guidelines for the care and use of animals and with an approved animal protocol from the Duke University Animal Care and Use Committee.

Materials. Morphine sulfate (Research Biochemicals, Natick, MA), desipramine, yohimbine, naloxone (Sigma, St. Louis, MO), and guanfacine (Tocris Cookson, Inc., Ballwin, MO) were prepared and administered as described in Nociceptive testing.

Nociceptive testing. Morphine sulfate (Research Biochemicals) was prepared in saline and administered subcutaneously. Desipramine and yohimbine or naloxone (Sigma) were prepared in water or saline, respectively, and administered via intraperitoneal injection. Guanfacine (Tocris Cookson, Inc.) was prepared in water and administered subcutaneously (Millan et al., 1994). Morphine-induced antinociception was evaluated by measuring response latencies in the warm water tail-flick and hot plate assays. Response latencies were measured as the amount of time the animal took 
to respond to the thermal stimuli (Bohn et al., 1999; Gainetdinov et al., $1999 \mathrm{~b})$. The warm water $\left(54^{\circ} \mathrm{C}\right)$ tail-flick test was performed by the use of a method similar to that described by Stone et al. (1997), and the response was defined as the removal of the tail from the warm water. In the hot plate $\left(56^{\circ} \mathrm{C}\right)$ test, the response was manifested as either paw licking or flicking. For both tests, the mice were not permitted to exceed $30 \mathrm{sec}$ of exposure to the thermal source to prevent prolonged painful stimulation. The reported data account for this artificial ceiling as well as for the basal responsiveness of each mouse to the test and are presented as the percent maximum possible effect (\% MPE) that is calculated by the following formula: $100 \% \times[($ drug response time - basal response time $) /(30 \mathrm{sec}-$ basal response time)] $=\%$ maximum possible effect (\% MPE).

Norepinephrine tissue content. The norepinephrine content in spinal cord tissue was determined by HPLC with electrochemical detection (HPLCEC) as described previously (Wang et al., 1997). Dissected spinal cords of adult mice were homogenized in $0.1 \mathrm{M} \mathrm{HClO}_{4}$ containing $100 \mathrm{ng} / \mathrm{ml}$ 3,4-dihydroxybenzylamine as an internal standard. Homogenates were centrifuged for $10 \mathrm{~min}$ at $10,000 \times g$. Supernatants were filtered through $0.22 \mu \mathrm{m}$ filters and analyzed for levels of NE using HPLC-EC. Monoamines and metabolites were separated on a microbore reverse-phase column (C-18, $5 \mu \mathrm{m}, 1 \times 150 \mathrm{~mm}$; Unijet; Bioanalytical Systems) with a mobile phase consisting of $50 \mathrm{~mm}$ monobasic sodium phosphate, $0.2 \mathrm{~mm}$ octyl sodium sulfate, $0.1 \mathrm{~mm}$ EDTA, $10 \mathrm{~mm} \mathrm{NaCl}$, and $10 \%$ methanol, $\mathrm{pH}$ 2.6, at a flow rate of $90 \mu \mathrm{l} / \mathrm{min}$ and were detected by a $3 \mathrm{~mm}$ glass carbon electrode (Unijet; Bioanalytical Systems) set at $+0.65 \mathrm{~V}$. The volume of the injection was $5 \mu l$.

Binding assays. Radioligand-binding assays were performed on membranes from mouse spinal cords prepared by Polytron homogenization in $50 \mathrm{~mm}$ Tris- $\mathrm{HCl}, \mathrm{pH} 7.4$, and centrifugation $(20,000 \times g)$. Homogenates were prepared by Dounce homogenization in $50 \mathrm{~mm}$ Tris- $\mathrm{HCl}$ buffer, and concentrations of $50 \mu \mathrm{g}$ per tube were used in each assay. Saturation binding assays for the $\alpha_{2 \mathrm{~A}} \mathrm{AR}, \alpha_{1} \mathrm{AR}$, and $\mu$-opioid receptor $(\mu \mathrm{OR})$ were performed with the respective antagonists $\left[{ }^{3} \mathrm{H}\right] \mathrm{RX} 821002(49 \mathrm{Ci} / \mathrm{mmol}$; Amersham, Piscataway, NJ), $\left[{ }^{3} \mathrm{H}\right]$ prazosin $(77 \mathrm{Ci} / \mathrm{mmol}$; NEN, Boston, $\mathrm{MA})$, and $\left[{ }^{3} \mathrm{H}\right]$ naloxone $(52 \mathrm{Ci} / \mathrm{mmol}$; Amersham). Increasing concentrations of each radioligand were incubated with membranes for $1 \mathrm{hr}$ at $25^{\circ} \mathrm{C}$. Nonspecific binding was determined with $10 \mu \mathrm{M}$ unlabeled naloxone or phentolamine as indicated. Membranes were collected by rapid filtration via a Brandel (Gaithersburg, MD) cell harvester onto GF/B filters and washed three times with cold $10 \mathrm{~mm}$ Tris buffer, pH 7.4 (Bohn et al., 1999).

Locomotor testing. Spontaneous open field locomotion and rearing behaviors of littermate wild-type and knock-out mice were measured in an Omnitech digiscan activity monitor $\left(42 \mathrm{~cm}^{2}\right)$. Activity studies were performed between the hours of 10 A.M. and 2 P.M. Locomotor activity was measured at $5 \mathrm{~min}$ intervals, and cumulative counts were taken for data analysis. To evaluate the effects of DMI on locomotor behavior, DMI or vehicle was injected intraperitoneally $30 \mathrm{~min}$ before testing, and different parameters of locomotor activity were monitored for the following $60 \mathrm{~min}$ as described previously (Gainetdinov et al., 1999a).

Swim-induced analgesia. The warm water swim-stress-induced analgesia paradigm was followed as described previously (Mogil et al., 1996; Rubinstein et al., 1996). Thirty minutes after basal nociception was measured, mice were placed in warm water $\left(33^{\circ} \mathrm{C}\right)$ and allowed to swim for $3 \mathrm{~min}$. They were then taken from the water and dried in a soft terrycloth towel and allowed to rest for $2 \mathrm{~min}$ before they were subjected to the tail-flick assay.

\section{RESULTS}

\section{Basal spinal nociceptive threshold is augmented in NET-KO mice}

Mice of each genotype were assessed for their responsiveness to pain using two classic antinociceptive tests: the "hot plate" and the warm water tail-flick assay. Although both genotypes respond equally to the hot plate test (Fig. $1 A$ ), the NET-KO mice display a significantly, although modestly, elevated pain threshold in the tail-flick test (Fig. 1B). These observations suggest that there is a slightly enhanced antinociceptive predisposition in mice that lack the NET.

\section{NE tissue content in spinal cord of WT and NET-KO mice}

The increase in basal antinociception revealed in the NET-KO mice may reflect changes in NE levels, because it has been shown that increasing NE (by blocking reuptake or by direct administration) can induce mild antinociception (Howe and Yaksh, 1982; Howe et al., 1983; Fleetwood-Walker et al., 1985; Yaksh, 1985; Solomon et al., 1989; Takano and Yaksh, 1992). Because these mutant mice lack the NE reuptake system, there exists the potential for elevated NE. Previously, we reported that NE levels in brain tissue were decreased by $\sim 50-70 \%$ and that this decrease in NE storage was accompanied by a greater than twofold increase

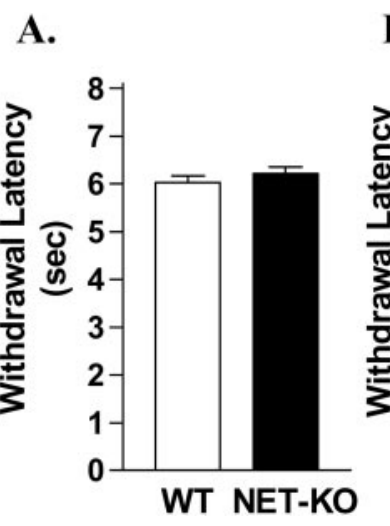

B.

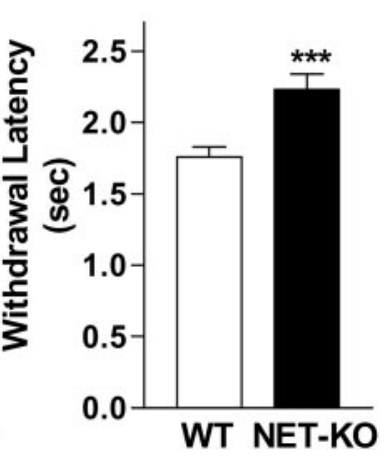

Figure 1. Basal antinociceptive thresholds in WT and NET-KO mice. Mice were subjected to the indicated test before any drug administrations. The average of their basal responses to the painful stimuli is presented here. $A$, Hot plate $\left(56^{\circ} \mathrm{C}\right)$ paw withdrawal latency. $B$, Warm water tail-flick $\left(54^{\circ} \mathrm{C}\right)$ tail withdrawal latency. Data are presented as the mean \pm SEM (** $p<0.01$; Student's $t$ test; $n=40-50$ mice).

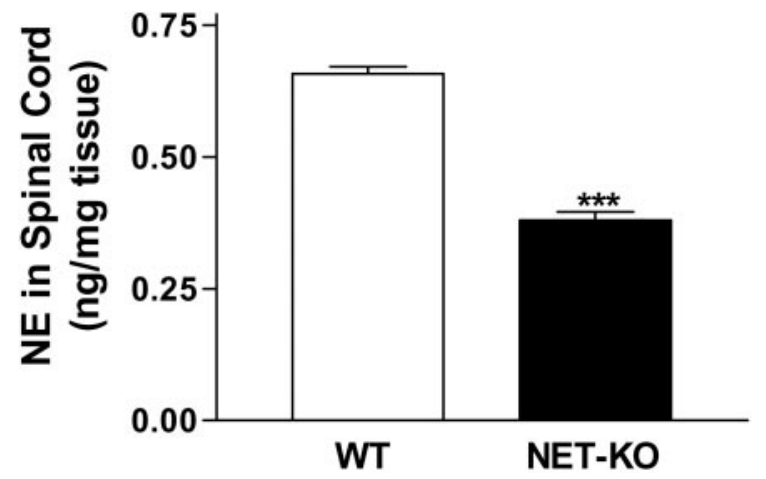

Figure 2. NE content in spinal cord tissue. NE levels were determined by HPLC-EC analysis of spinal cords of WT and NET-KO mice $(* * * p<$ 0.001 ; Student's $t$ test; $n=6$ of each genotype).

in extracellular NE levels (Xu et al., 2000). Similar results were described previously for the homeostatic control of dopamine and serotonin in dopamine transporter- and serotonin transporter (SERT)-KO mice, respectively (Jones et al., 1998; Murphy et al., 1998). Altogether, these observations support a generalized principle that decreased storage and a corresponding increase in extracellular transmitter levels occur in neuronal systems without active transport (Gainetdinov et al., 1998; Jones et al., 1998; Xu et al., 2000). Using the same approach, we evaluated the NE content in spinal cord tissue from WT and NET-KO mice by HPLC-EC analysis (Fig. 2). Although technical limitations prevent reliable assessment of extracellular NE levels in the spinal cord of mice, the $50 \%$ decrease of tissue NE levels detected in NET-KO mice strongly suggests altered NE homeostasis in a manner similar to that seen in brain tissues. Thus, increased extracellular NE levels in the spinal cord can reasonably be inferred in NET-KO mice.

\section{Enhanced effects of morphine analgesia revealed in NET-KO mice}

To assess the effects of opiate treatment in mice that genetically lack the NET, increasing doses of morphine were administered, and analgesia was assessed after $20 \mathrm{~min}$ by both the hot plate and tail-flick methods. In the hot plate test, each genotype responded to morphine in a dose-dependent manner, revealing no difference between the two genotypes (Fig. $3 A$ ). In the tail-flick test, however, morphine analgesia was significantly enhanced in the NET-KO mice (Fig. $3 B$ ). This striking difference in the potency of morphine between the genotypes in the tail-flick test may reflect enhanced spinal antinociception. Similar enhancement of spinal antinociception has been described previously in the synergistic actions of 
A.

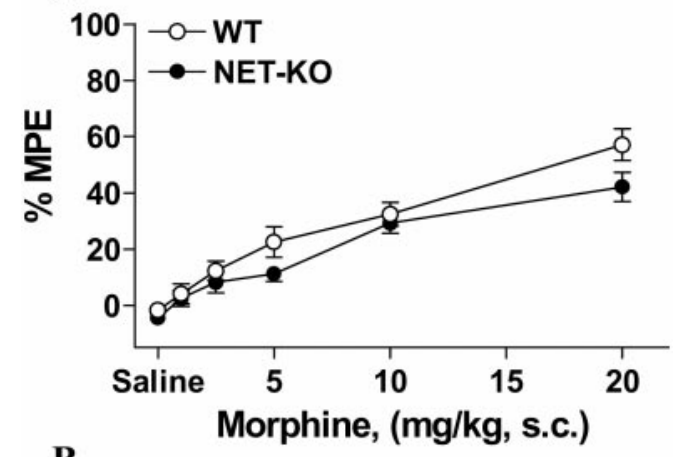

B.

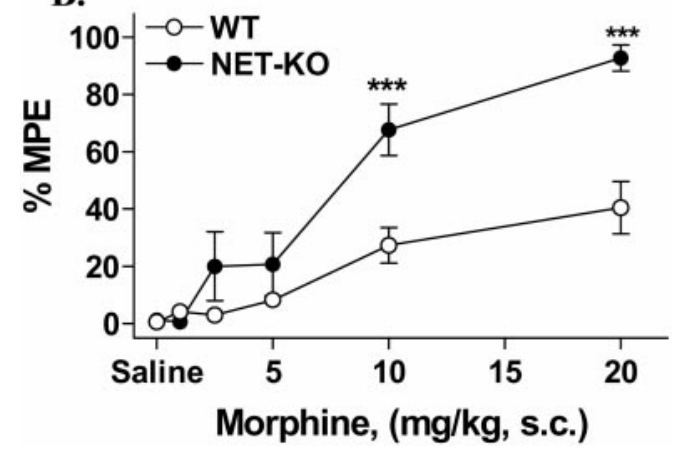

Figure 3. Morphine-induced analgesia in the tail-flick assay. WT and NET-KO mice were injected subcutaneously with the indicated dose of morphine, and antinociception was measured after $20 \mathrm{~min}$. $A$, Hot plate $\left(56^{\circ} \mathrm{C}\right)$ response latencies. $B$, Tail-flick $\left(54^{\circ} \mathrm{C}\right)$ response latencies. NET-KO mice experienced significantly greater analgesia than did WT mice at 10 and $20 \mathrm{mg} / \mathrm{kg}$ morphine. Data are presented as the mean \pm SEM $(* * * p<$ 0.001 ; Student's $t$ test; $n=9-19$ mice/dose).

morphine and adrenergic agonists (Howe and Yaksh, 1982; Howe et al., 1983; Fleetwood-Walker et al., 1985; Yaksh, 1985; Solomon et al., 1989; Takano and Yaksh, 1992).

\section{Adrenergic and opioid receptor-binding profiles}

To ascertain whether receptor-binding profiles were altered in the NET-KO mice, radioligand-binding analyses were preformed. Because previous work implicates the $\mu \mathrm{OR}$ as well as the $\alpha_{2 \mathrm{~A}} \mathrm{AR}$ subtypes in the opioidergic-adrenergic-potentiated antinociception, levels of these receptors were determined in preparations of spinal cord membranes. Binding of the $\alpha_{2 \mathrm{~A}}$ AR-preferring antagonist $\left[{ }^{3} \mathrm{H}\right] \mathrm{RX} 821002$ did not vary between the genotypes, nor did the binding of $\left[{ }^{3} \mathrm{H}\right]$ naloxone, indicating that the $\alpha_{2 \mathrm{~A}} \mathrm{AR}$ and $\mu \mathrm{OR}$ levels in the spinal cord of WT and NET-KO mice are not significantly different (Table 1). Therefore, changes in morphine sensitivity in the mutant mice are probably not caused by increases in receptor numbers. In addition, $\alpha_{1} \mathrm{AR}$-binding parameters were also measured in spinal cord membrane preparations using $\left[{ }^{3} \mathrm{H}\right]$ prazo$\sin$. Although the $K_{\mathrm{D}}$ for the ligand showed no difference, a $>50 \%$ decrease in $\alpha_{1} \mathrm{AR}$ number was observed similar to that seen in hippocampal membranes prepared from the NET-KO mice (Xu et al., 2000). This downregulation of $\alpha_{1} \mathrm{AR}$ is consistent with increased levels of NE in these mice.

\section{Enhanced morphine analgesia in NET-KO mice is caused by activation of $\alpha_{2}$ ARs}

The blockade (via TCAs) or loss (via genetic deletion) of the NET may lead to increased NE in the spinal cord, resulting in increased activation of the $\alpha_{2} \mathrm{AR}$. Because the $\alpha_{2 \mathrm{~A}} \mathrm{AR}$ subtype has been implicated in the opioid-adrenergic synergy of spinal antinociception (Millan et al., 1994; Graham et al., 1997; Stone et al., 1998), guanfacine, a preferential agonist at the $\alpha_{2 \mathrm{~A}} \mathrm{AR}$ (Millan et al., 1994), was administered before morphine in both NET-KO and their WT controls. Guanfacine enhanced morphine analgesia in WT mice in a dose-dependent manner, resulting in the same degree of antinociception as that observed for morphine alone in NET-KO mice (Fig. 4A). Interestingly, guanfacine had no significant further effect on morphine analgesia when given to the NET-KO mice (Fig. 4A). Guanfacine, when give alone, produced mild analgesia $(11.8 \pm 1 \% \mathrm{MPE})$ in $\mathrm{WT}$ mice and had a similar effect on NET-KO mice $(10.6 \pm 3.1 \% \mathrm{MPE})$. To test further the involvement of $\alpha_{2} \mathrm{AR}$ signaling in the apparent enhancement of morphine analgesia, yohimbine, an $\alpha_{2} \mathrm{AR}$ antagonist, was used (Fig. 4B). Whereas yohimbine had no effect on analgesia in WT mice after morphine treatment, in the NET-KO mice it reversed the enhanced morphine response to the same level observed in WT mice after morphine treatment alone (Fig. 4B). Taken together, these results suggest that the enhanced effects of morphine in the NET-KO mice are caused by activation of $\alpha_{2} \mathrm{ARs}$ and that this phenomenon can be recapitulated in WT mice after coadministration of morphine and an $\alpha_{2 \mathrm{~A}} \mathrm{AR}$-preferring agonist.

\section{Desipramine enhances morphine analgesia in WT but not NET-KO mice}

The degree of enhanced morphine analgesia in the NET-KO mice is similar to that seen in previous studies in which normal mice were coadministered morphine and DMI or morphine and $\alpha_{2} \mathrm{AR}$ agonists (Kellstein et al., 1984; Fairbanks and Wilcox, 1999; Reimann et al., 1999), suggesting that the loss of NET results in greater tonic activation of the $\alpha_{2} \mathrm{AR}$ system in the NET-KO mice. After a $2 \mathrm{hr}$ pretreatment with DMI $(2.5,10$, or $20 \mathrm{mg} / \mathrm{kg}$, i.p. $)$, we found that morphine analgesia was enhanced in WT littermates to the same extent as that seen in NET-KO mice receiving only morphine (Fig. 5). Interestingly, DMI at this dose had no apparent effect on morphine analgesia in NET-KO mice, suggesting that the antinociceptive contributions of this TCA are primarily caused by blockade of the NET.

\section{Desipramine retains some effects in the NET-KO mice}

In rodents, acute administration of DMI produces an inhibitory effect on locomotor activity (Tucker and File, 1986). To assess whether DMI elicits this inhibitory effect exclusively via interaction with the NET, we monitored WT and NET-KO mice for horizontal and vertical locomotor activity after acute drug administration. As we described previously, the NET-KO mice demonstrate markedly lower basal levels of both horizontal and vertical activities when exposed to a new environment [Fig. 6, vehicle (saline) treated] (Xu et al., 2000). Pretreatment with DMI (10 mg/kg, i.p.) induces significant inhibitory effects in WT mice (Fig. 6). Despite lower levels of spontaneous activity, the NET-KO mice retained some degree of sensitivity to the inhibitory effects of DMI on locomotor behavior (two-way ANOVA, $p<0.01$ ). Thus, desipramine still elicits some behavioral effects in mice lacking the NET.

\section{Endogenous opioid effects are enhanced in NET-KO mice}

Because the effects of an exogenous opioid such as morphine could be so dramatically enhanced in mice lacking the NET, we evaluated the effects of endogenous opioids in these mice. A 3 min swim in warm $\left(30-33^{\circ} \mathrm{C}\right)$ water has been shown previously to induce mild endogenous opioid-mediated analgesia in mice (Mogil et al., 1996; Rubinstein et al., 1996). After this swim-stress paradigm, low levels of antinociception could be detected by the warm water tail-flick assay in the WT mice; however, antinociception in NET-KO mice was dramatically induced (Fig. 7). To demonstrate that this induction of antinociception was mediated via the activation of opioidergic systems, naloxone, the OR antagonist, was used to block completely the analgesic effects of the swim stress (Fig. 7). Naloxone alone had no significant effect on the tail withdrawal latency of either genotype (data not shown).

\section{DISCUSSION}

These studies demonstrate that the NET-KO mice experience enhanced opioid analgesia as compared with WT mice as well as a modest increase in basal nociceptive thresholds. We have provided 
Table 1. Saturation binding of $\alpha_{2 \mathrm{~A}} \mathrm{AR}$ and $\mu \mathrm{OR}$ in WT and NET-KO mouse spinal cord

\begin{tabular}{|c|c|c|c|c|}
\hline & \multicolumn{2}{|l|}{ WT } & \multicolumn{2}{|l|}{ NET-KO } \\
\hline & $\begin{array}{l}B_{\mathrm{MAx}} \\
(\mathrm{fmol} / \mathrm{mg} \text { of protein) }\end{array}$ & $\begin{array}{l}K_{\mathrm{D}} \\
(\mathrm{nM})\end{array}$ & $\begin{array}{l}B_{\mathrm{MAX}} \\
(\mathrm{fmol} / \mathrm{mg} \text { of protein) }\end{array}$ & $\begin{array}{l}K_{\mathrm{D}} \\
(\mathrm{nM})\end{array}$ \\
\hline$\left[{ }^{3} \mathrm{H}\right] \mathrm{RX} 821002$ & $193 \pm 21$ & $0.17 \pm 0.01$ & $216 \pm 21$ & $0.28 \pm 0.05$ \\
\hline$\left[{ }^{3} \mathrm{H}\right]$ Prazosin & $76 \pm 3$ & $0.20 \pm 0.01$ & $35 \pm 2 * *$ & $0.14 \pm 0.03$ \\
\hline$\left[{ }^{3} \mathrm{H}\right]$ Naloxone & $121 \pm 7$ & $2.3 \pm 0.3$ & $112 \pm 17$ & $2.8 \pm 0.4$ \\
\hline
\end{tabular}

Membranes were prepared from mouse spinal cords, and saturation binding curves were performed. The $\alpha_{2 \mathrm{~A}} \mathrm{AR}$ antagonist $\left[{ }^{3} \mathrm{H}\right] \mathrm{RX} 821002(0.2-10 \mathrm{nM})$, the $\alpha_{1} \mathrm{AR}$ antagonist $\left[{ }^{3} \mathrm{H}\right]$ prazosin $(0.1-3 \mathrm{~nm})$, and low concentrations of the opioid receptor antagonist $\left[{ }^{3} \mathrm{H}\right]$ naloxone $(0.2-10 \mathrm{nM})$ were used to assess binding parameters of the respective receptors. Specific binding was determined by performing the experiments in the presence of either phentolamine (10 $\mu \mathrm{M}$ for $\alpha_{2 \mathrm{~A}} \mathrm{AR}$ and $5 \mu \mathrm{M}$ for $\left.\alpha_{1} \mathrm{AR}\right)$ or naloxone (10 $\mu \mathrm{M}$ for $\mu \mathrm{OR}$ ). Presented are binding parameters obtained from Scatchard analysis using the GraphPad Prism software. Data are the mean \pm SEM of three experiments performed in duplicate.

${ }^{* *} p<0.001$, versus WT, Student's $t$ test.

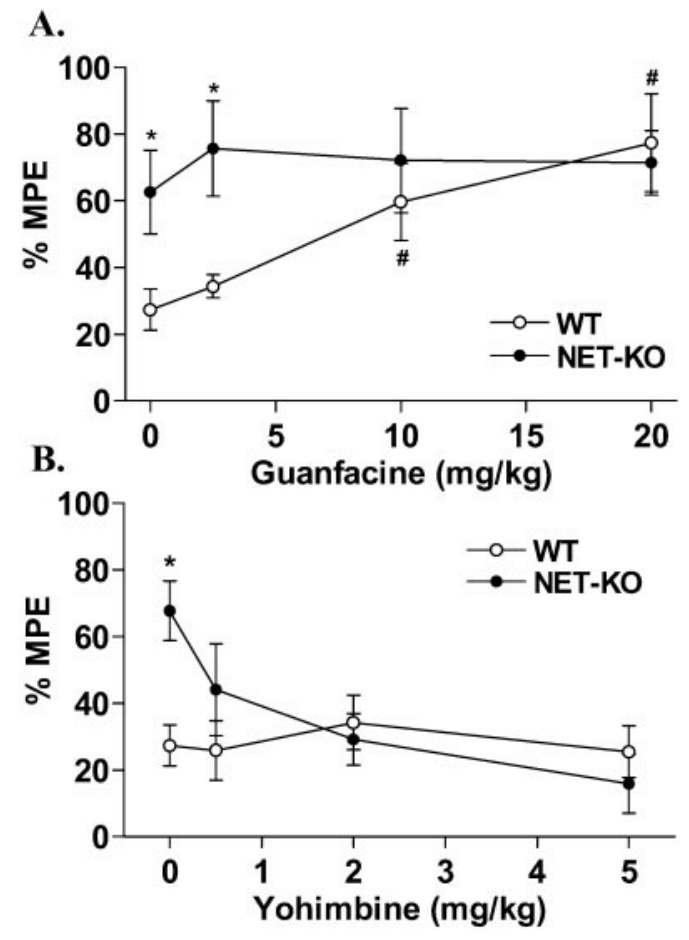

Figure 4. Role of $\alpha_{2} \mathrm{AR}$ in the tail-flick assay. $A$, The $\alpha_{2 \mathrm{~A}} \mathrm{AR}$ agonist guanfacine $(2.5,10$, and $20 \mathrm{mg} / \mathrm{kg}$, s.c.), when given $10 \mathrm{~min}$ before morphine, enhances morphine $(10 \mathrm{mg} / \mathrm{kg}$, s.c.; $20 \mathrm{~min})$ analgesia in WT mice to the same extent that morphine alone enhances analgesia in the NET-KO mice. Guanfacine $(10 \mathrm{mg} / \mathrm{kg}$, s.c.) alone induced mild analgesia in WT mice $(11.8 \pm 1.0 \% \mathrm{MPE})$ and NET-KO mice $(10.6 \pm 3.1 \% \mathrm{MPE}) . B$, The $\alpha_{2} \mathrm{AR}$ antagonist yohimbine $(0.5,2$, and $5 \mathrm{mg} / \mathrm{kg}$, s.c. $)$ reverses potentiated morphine analgesia in NET-KO mice when given $10 \mathrm{~min}$ before morphine $(10$ $\mathrm{mg} / \mathrm{kg}$, s.c.; $20 \mathrm{~min})$. Data are presented as the mean \pm SEM [ ${ }^{*} p<0.01$, vs $\mathrm{WT} ; p<0.01$, vs WT $(0,2.5 \mathrm{mg} / \mathrm{kg}$ guanfacine); Student's $t$ test; $n=5-9$ mice/dose].

evidence that the loss of the NET results in increased extracellular $\mathrm{NE}$ (Xu et al., 2000) (Fig. 2) and that this increase in the extracellular concentrations of the neurotransmitter contributes to the increasing pain thresholds by acting at the $\alpha_{2 \mathrm{~A}} \mathrm{AR}$. The increase in basal nociceptive thresholds seen in the NET-KO mice in the tail-flick but not the hot plate test suggests that these effects may predominantly involve spinal noradrenergic systems, a suggestion that is in agreement with previous observations (Hylden and Wilcox, 1983; Wilcox et al., 1987; Ossipov et al., 1990a,b). Furthermore, $\alpha_{2 \mathrm{~A}} \mathrm{ARs}$ are robustly present in spinal cord neurons (Stone et al., 1998), and agonists at these receptors are known to prolong tailflick latencies (Reddy et al., 1980; Yasuoka and Yaksh, 1983; Milne et al., 1985; Solomon et al., 1989; Lakhlani et al., 1997).

Although basal antinociception is only modestly enhanced in the NET-KO mice, greater differences between the genotypes can be

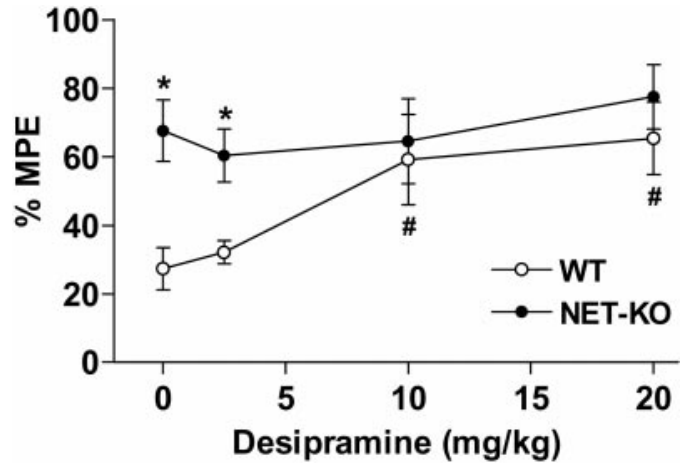

Figure 5. Effects of DMI on antinociception in the tail-flick assay. WT and NET-KO mice were first injected with DMI $(2.5,10$, and $20 \mathrm{mg} / \mathrm{kg}$, i.p. $) ; 2$ $\mathrm{hr}$ later, mice were treated with morphine $(10 \mathrm{mg} / \mathrm{kg}$, s.c. $)$, and tail-flick latencies were measured after $20 \mathrm{~min}$. Data are presented as the mean \pm SEM $\left[{ }^{*} p<0.01\right.$, vs WT; $p<0.01$, vs WT $(0,2.5 \mathrm{mg} / \mathrm{kg}$ desipramine $)$; Student's $t$ test; $n=8-18$ mice/dose].

clearly seen after administration of morphine. Many strains of mice, as well as the WT and the parental lines used to generate this transgenic line, reach moderate analgesia $(\sim 30-50 \% \mathrm{MPE}$ as measured in this assay) 20-30 min after a dose of morphine (10 $\mathrm{mg} / \mathrm{kg}$, s.c.; data not shown). The NET-KO mice display significantly enhanced morphine analgesia at this dose as compared with the WT controls (Fig. 3).

Previous studies have demonstrated consistently that morphine analgesia is potentiated after coadministration of $\alpha_{2} \mathrm{AR}$ agonists. Both $\mu$ and $\delta$ opioid receptors have been implicated as targets mediating the effects of morphine in the antinociception potentiated by $\alpha_{2}$ AR agonists (Ossipov et al., 1990b; Roerig et al., 1992; Stone et al., 1997; Grabow et al., 1999). Moreover, because of a lack of pharmacologically selective agents, it had remained uncertain which subtype of $\alpha_{2} \mathrm{ARs}$ is targeted by agonists, such as clonidine and norepinephrine, in modulating spinal transmission of pain, although many studies now suggest that the $\alpha_{2 \mathrm{~A}} \mathrm{AR}$ plays a prominent role (Millan et al., 1994; Graham et al., 1997; Lakhlani et al., 1997). This observation is recapitulated in the WT littermates of the NET-KO mice (Fig. $4 A$ ) using the selective $\alpha_{2 \mathrm{~A}} \mathrm{AR}$ agonist guanfacine (Millan, 1992). Interestingly, the WT mice treated with both guanfacine and morphine experience the same extent of analgesia as do the NET-KO mice treated only with morphine. This suggests that in the NET-KO mice, the $\alpha_{2 \mathrm{~A}} \mathrm{AR}$ component is already stimulated and that additional agonist treatment has no effect. This supposition was confirmed by using the $\alpha_{2}$ AR antagonist yohimbine (Howe et al., 1983; Takano and Yaksh, 1992), which eliminates the enhanced effects of morphine analgesia, causing the NET-KO mice to respond to morphine to the same extent as do WT mice (Fig. 4B). Interestingly, these data suggest that the tonically elevated NE does not seem to lead to functional desensitization of the adrenergic response. In addition, although we see a 

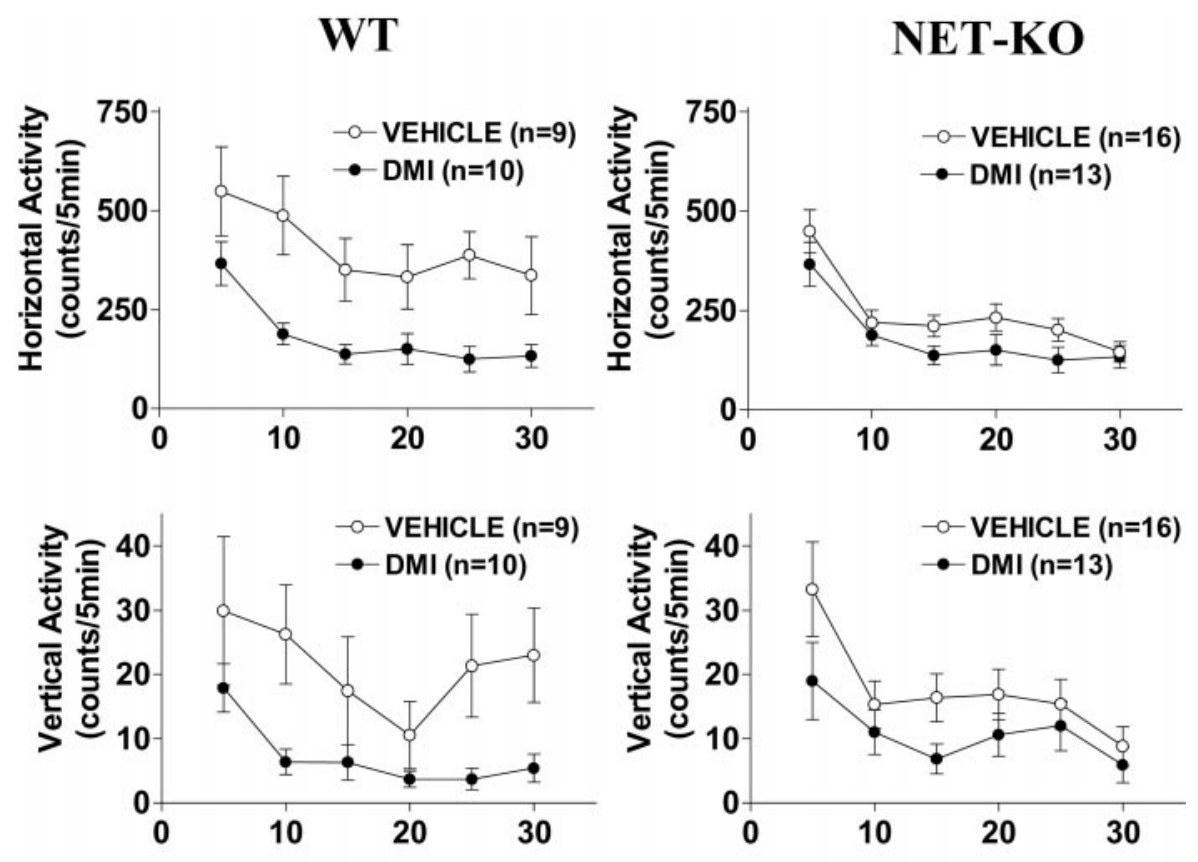

Figure 6. Effect of DMI on locomotor activity. The effect of DMI $(10 \mathrm{mg} / \mathrm{kg}$, i.p.) on the horizontal NET-KO (right) mice is shown. DMI significantly depresses horizontal and vertical activities in both genotypes $(p<0.01$ vs vehicle-treated controls; twoway ANOVA). Numbers of animal per group are depicted on the figure.

\section{Time (minutes)}

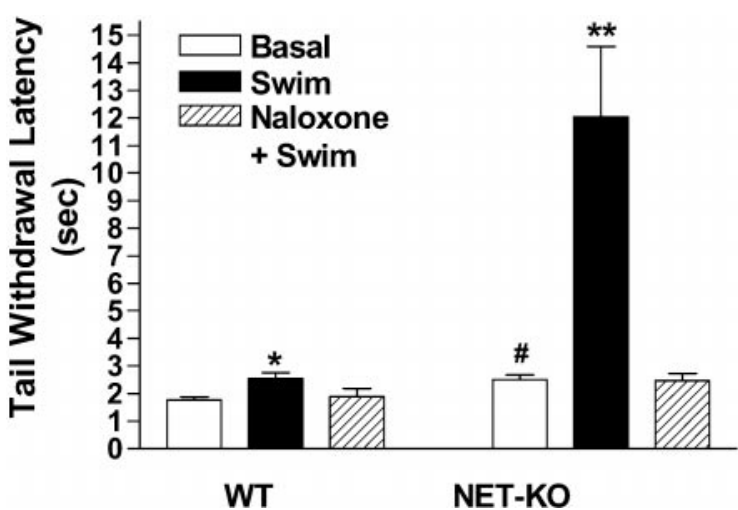

Figure 7. Warm water swim-stress-induced antinociception. Antinociception was assessed by the tail-flick assay after the warm water swim. The endogenous opioid-mediated analgesia could be reversed by pretreating mice with the opioid receptor antagonist naloxone $(2 \mathrm{mg} / \mathrm{kg}$, s.c. $) 20 \mathrm{~min}$ before the swim. Data are the mean \pm SEM $(* p<0.1$, vs WT basal; $* * p<$ 0.001 , vs NET-KO basal; ${ }^{\#} p<0.001$, vs NET-KO after the swim; one-way ANOVA followed by a Tukey post test).

downregulation of $\alpha_{1} \mathrm{AR}$, the number of $\alpha_{2 \mathrm{~A}} \mathrm{ARs}$ does not change in the NET-KO mice. This is in agreement with previous observations that the $\alpha_{2 \mathrm{~A}} \mathrm{AR}$ resists downregulation in the presence of chronic agonist (Daunt et al., 1997; Saunders and Limbird, 1999).

Additionally, we were able to recreate the effect of potentiated morphine analgesia in the presence of elevated levels of $\alpha_{2} \mathrm{AR}$ agonists or TCAs in the absence of any drug treatment. By inducing opioid release by the swim-stress-induced analgesia paradigm, the nociceptive threshold was raised in the NET-KO mice to the same extent that it was raised in WT mice treated with morphine alone. This elevation in nociceptive thresholds in the NET-KO mice indicates that endogenous opioid-mediated analgesia can be significantly potentiated by elevation of NE in the mouse.

In studies in both humans and mice, TCAs have proven to be effective in inducing mild analgesia. However, such transporter blockers appear to be nonselective in vivo, making it hard to discriminate between their actions at other monoamine uptake sites (for review, see Chen and Reith, 1997). Additionally, there are reports in the literature that suggest that DMI may bind directly to opioid receptors, thereby contributing to their analgesic properties (Biegon and Samuel, 1980). However, it is generally accepted that the DMI provides moderate analgesia because of the blockade of $\mathrm{NE}$ reuptake and the consequent activation of the $\alpha_{2} \mathrm{AR}$. The generation of transgenic mice lacking the NET has made it possible to assess directly the contribution of blocking the specific transporter to the induction of antinociception.

The results of the present study directly demonstrate that analgesic effects of DMI can be attributed to interactions with the NET. However this is not the case for the inhibitory effect of DMI on behavior. Previously, we have shown that NET-KO mice are hypoactive in a new environment, and this hypoactivity was correlated with lower levels of extracellular dopamine (DA) in the striatum (Xu et al., 2000). Despite this fact, DMI was able to induce further inhibitory effects on the activity of these mice. Thus it is likely that DMI may have two independent effects on locomotor activity; one may be related to secondary alterations in the midbrain DA system, and the other may be via interactions of the drug with targets other than the NET. The most likely candidate for this additional effect of DMI is the SERT, which is consistent with the established inhibitory effect of serotonin on novelty-provoked locomotor activity (Lucki, 1998; Gainetdinov et al., 1999a).

In conclusion, these data demonstrate that genetic elimination of the NET results in enhanced antinociception and that this is attributable to increased activation of the target of NE, the $\alpha_{2 \mathrm{~A}} \mathrm{R}$. Moreover, these data illustrate that the NET is required for the analgesic but not the locomotor inhibitory properties mediated by DMI in mice. Finally, these observations support the idea that an elevation of $\mathrm{NE}$ by blockade of the transporter results in potentiated morphine-induced spinal antinociception.

\section{REFERENCES}

Biegon A, Samuel D (1980) Interaction of tricyclic antidepressants with opiate receptors. Biochem Pharmacol 29:460-462.

Bohn LM, Lefkowitz RJ, Gainetdinov RR, Peppel K, Caron MG, Lin FT (1999) Enhanced morphine analgesia in mice lacking beta-arrestin 2. Science 286:2495-2498.

Chen N-H, Reith MEA (1997) Role of axonal and somatodendritic monoamine transporters in action of uptake blockers. In: Neurotransmitter transporters: structure, function, and regulation (Reith MEA, ed), pp 345-391. Totowa, NJ: Humana.

Daunt DA, Hurt C, Hein L, Kallio J, Feng F, Kobilka BK (1997) Subtypespecific intracellular trafficking of $\alpha 2$-adrenergic receptors. Mol Pharmacol 51:711-720. 
Davis KD, Treede RD, Raja SN, Meyer RA, Campbell JN (1991) Topical application of clonidine relieves hyperalgesia in patients with sympathetically maintained pain. Pain 47:309-317.

Eisenach JC, DuPen S, Dubois M, Miguel R, Allin D (1995) Epidural clonidine analgesia for intractable cancer pain. The Epidural Clonidine Study Group. Pain 61:391-399.

Eisenach JC, De Kock M, Klimscha W (1996) Alpha(2)-adrenergic agonists for regional anesthesia. A clinical review of clonidine (1984-1995) Anesthesiology 85:655-674.

Fairbanks CA, Wilcox GL (1999) Spinal antinociceptive synergism between morphine and clonidine persists in mice made acutely or chronically tolerant to morphine. J Pharmacol Exp Ther 288:1107-1116.

Fleetwood-Walker SM, Mitchell R, Hope PJ, Molony V, Iggo A (1985) An alpha 2 receptor mediates the selective inhibition by noradrenaline of nociceptive responses of identified dorsal horn neurones. Brain Res 334:243-254.

Gainetdinov RR, Jones SR, Fumagalli F, Wightman RM, Caron MG (1998) Re-evaluation of the role of the dopamine transporter in dopamine system homeostasis. Brain Res Brain Res Rev 26:148-153.

Gainetdinov RR, Wetsel WC, Jones SR, Levin ED, Jaber M, Caron MG (1999a) Role of serotonin in the paradoxical calming effect of psychostimulants on hyperactivity. Science 283:397-401.

Gainetdinov RR, Bohn LM, Walker JK, Laporte SA, Macrae AD, Caron MG, Lefkowitz RJ, Premont RT (1999b) Muscarinic supersensitivity and impaired receptor desensitization in $\mathrm{G}$ protein-coupled receptor kinase 5-deficient mice. Neuron 24:1029-1036.

Grabow TS, Hurley RW, Banfor PN, Hammond DL (1999) Supraspinal and spinal delta(2) opioid receptor-mediated antinociceptive synergy is mediated by spinal alpha(2) adrenoceptors. Pain 83:47-55.

Graham BA, Hammond DL, Proudfit HK (1997) Differences in the antinociceptive effects of alpha-2 adrenoceptor agonists in two substrains of Sprague-Dawley rats. J Pharmacol Exp Ther 283:511-559.

Gray AM, Spencer PS, Sewell RD (1998) The involvement of the opioidergic system in the antinociceptive mechanism of action of antidepressant compounds. Br J Pharmacol 124:669-674.

Gray AM, Pache DM, Sewell RD (1999) Do alpha2-adrenoceptors play an integral role in the antinociceptive mechanism of action of antidepressant compounds? Eur J Pharmacol 378:161-168.

Howe JR, Yaksh TL (1982) Changes in sensitivity to intrathecal norepinephrine and serotonin after 6-hydroxydopamine (6-OHDA), 5,6dihydroxytryptamine $(5,6-\mathrm{DHT})$ or repeated monoamine administration. J Pharmacol Exp Ther 220:311-321.

Howe JR, Wang JY, Yaksh TL (1983) Selective antagonism of the antinociceptive effect of intrathecally applied alpha adrenergic agonists by intrathecal prazosin and intrathecal yohimbine. J Pharmacol Exp Ther 224:552-558.

Hwang AS, Wilcox GL (1987) Analgesic properties of intrathecally administered heterocyclic antidepressants. Pain 28:343-355.

Hylden JL, Wilcox GL (1983) Pharmacological characterization of substance P-induced nociception in mice: modulation by opioid and noradrenergic agonists at the spinal level. J Pharmacol Exp Ther 226:398-404.

Jones SR, Gainetdinov RR, Jaber M, Giros B, Wightman RM, Caron MG (1998) Profound neuronal plasticity in response to inactivation of the dopamine transporter. Proc Natl Acad Sci USA 95:4029-4034.

Kellstein DE, Malseed RT, Goldstein FJ (1984) Contrasting effects of acute vs. chronic tricyclic antidepressant treatment on central morphine analgesia. Pain 20:323-334.

Kellstein DE, Malseed RT, Ossipov MH, Goldstein FJ (1988) Effect of chronic treatment with tricyclic antidepressants upon antinociception induced by intrathecal injection of morphine and monoamines. Neuropharmacology 27:1-14.

Lakhlani PP, MacMillan LB, Guo TZ, McCool BA, Lovinger DM, Maze M, Limbird LE (1997) Substitution of a mutant alpha2a-adrenergic receptor via "hit and run" gene targeting reveals the role of this subtype in sedative, analgesic, and anesthetic-sparing responses in vivo. Proc Natl Acad Sci USA 94:9950-9955.

Lucki I (1998) The spectrum of behaviors influenced by serotonin. Biol Psychiatry 44:151-162.

Millan MJ (1992) Evidence that an alpha 2A-adrenoceptor subtype mediates antinociception in mice. Eur J Pharmacol 215:355-356.

Millan MJ, Bervoets K, Rivet JM, Widdowson P, Renouard A, Le Marouille-Girardon S, Gobert A (1994) Multiple alpha-2 adrenergic receptor subtypes. II. Evidence for a role of rat R alpha-2A adrenergic receptors in the control of nociception, motor behavior and hippocampal synthesis of noradrenaline. J Pharmacol Exp Ther 270:958-972.

Milne B, Cervenko FW, Jhamandas K, Sutak M (1985) Intrathecal clonidine: analgesia and effect on opiate withdrawal in the rat. Anesthesiology 62:34-38.

Mogil JS, Sternberg WF, Balian H, Liebeskind JC, Sadowski B (1996) Opioid and nonopioid swim stress-induced analgesia: a parametric analysis in mice. Physiol Behav 59:123-132.

Murphy DL, Andrews AM, Wichems CH, Li Q, Tohda M, Greenberg B (1998) Brain serotonin neurotransmission: an overview and update with an emphasis on serotonin subsystem heterogeneity, multiple receptors, interactions with other neurotransmitter systems, and consequent implications for understanding the actions of serotonergic drugs. J Clin Psychiatry $59: 4-12$.

Ossipov MH, Harris S, Lloyd P, Messineo E (1990a) An isobolographic analysis of the antinociceptive effect of systemically and intrathecally administered combinations of clonidine and opiates. J Pharmacol Exp Ther 255:1107-1116.

Ossipov MH, Lozito R, Messineo E, Green J, Harris S, Lloyd P (1990b) Spinal antinociceptive synergy between clonidine and morphine, U69593, and DPDPE: isobolographic analysis. Life Sci 47:L71-L76.

Reddy SV, Maderdrut JL, Yaksh TL (1980) Spinal cord pharmacology of adrenergic agonist-mediated antinociception. J Pharmacol Exp Ther 213:525-533.

Reimann W, Schlutz H, Selve N (1999) The antinociceptive effects of morphine, desipramine, and serotonin and their combinations after intrathecal injection in the rat. Anesth Analg 88:141-145.

Roerig SC, Lei S, Kitto K, Hylden JK, Wilcox GL (1992) Spinal interactions between opioid and noradrenergic agonists in mice: multiplicativity involves delta and alpha-2 receptors. J Pharmacol Exp Ther 262:365-374.

Rubinstein M, Mogil JS, Japon M, Chan EC, Allen RG, Low MJ (1996) Absence of opioid stress-induced analgesia in mice lacking betaendorphin by site-directed mutagenesis. Proc Natl Acad Sci USA 93:3995-4000.

Saunders C, Limbird LE (1999) Localization and trafficking of $\alpha 2$ adrenergic receptor subtypes in cells and tissues. Pharmacol Ther 84:193-205.

Solomon RE, Brody MJ, Gebhart GF (1989) Pharmacological characterization of alpha adrenoceptors involved in the antinociceptive and cardiovascular effects of intrathecally administered clonidine. J Pharmacol Exp Ther 251:27-38.

Stone LS, MacMillan LB, Kitto KF, Limbird LE, Wilcox GL (1997) The alpha2a adrenergic receptor subtype mediates spinal analgesia evoked by alpha2 agonists and is necessary for spinal adrenergic-opioid synergy. J Neurosci 17:7157-7165.

Stone LS, Broberger C, Vulchanova L, Wilcox GL, Hokfelt T, Riedl MS, Elde R (1998) Differential distribution of alpha2A and alpha2C adrenergic receptor immunoreactivity in the rat spinal cord. J Neurosci 18:5928-5937.

Takano Y, Yaksh TL (1992) Characterization of the pharmacology of intrathecally administered alpha-2 agonists and antagonists in rats. J Pharmacol Exp Ther 261:764-772.

Tucker JC, File SE (1986) The effects of tricyclic and "atypical" antidepressants on spontaneous locomotor activity in rodents. Neurosci Biobehav Rev 10:115-121.

Tura B, Tura SM (1990) The analgesic effect of tricyclic antidepressants. Brain Res 518:19-22.

Wang YM, Gainetdinov RR, Fumagalli F, Xu F, Jones SR, Bock CB, Miller GW, Wightman RM, Caron MG (1997) Knockout of the vesicular monoamine transporter 2 gene results in neonatal death and supersensitivity to cocaine and amphetamine. Neuron 19:1285-1296.

Wang YM, Xu F, Gainetdinov RR, Caron MG (1999) Genetic approaches to studying norepinephrine function: knockout of the mouse norepinephrine transporter gene. Biol Psychiatry 46:1124-1130.

Ward NG, Bloom VL, Friedel RO (1979) The effectiveness of tricyclic antidepressants in the treatment of coexisting pain and depression. Pain 7:331-341

Wilcox GL, Carlsson KH, Jochim A, Jurna I (1987) Mutual potentiation of antinociceptive effects of morphine and clonidine on motor and sensory responses in rat spinal cord. Brain Res 405:84-93.

Xu F, Gainetdinov RR, Wetsel WC, Jones SR, Bohn LM, Miller GW, Wang YM, Caron MG (2000) Mice lacking the norepinephrine transporter are supersensitive to psychostimulants. Nat Neurosci 3:465-471.

Yaksh TL (1985) Pharmacology of spinal adrenergic systems which modulate spinal nociceptive processing. Pharmacol Biochem Behav 22:845-858.

Yasuoka S, Yaksh TL (1983) Effects on nociceptive threshold and blood pressure of intrathecally administered morphine and alpha-adrenergic agonists. Neuropharmacology 22:309-315. 